\title{
Quality of Life as A Predictor of Happiness and Life Satisfaction
}

\author{
Langgersari Elsari Novianti ${ }^{1}$, Esti Wungu' ${ }^{2}$, Fredrick Dermawan Purba ${ }^{3}$ \\ Faculty of Psychology, Universitas Padjadjaran
}

\section{Submitted 14 July 2019 Accepted 31 January 2020 Published 24 August 2020}

\begin{abstract}
This study aimed to find correlations between the quality of life, happiness, and life satisfaction of the general population of Bandung city. There were 370 participants with average age of 20.7 years, mostly male (55.7\%) and with a secondary level of education (SMP-SMA; 57.0\%) who completed three questionnaires: (i) WHOQOL-BREF to measure quality of life, (ii) Happiness Thermometer to measure happiness, and (iii) SelfAnchoring Cantril Striving Scale to measure life satisfaction. Multiple linear regression tests were used with happiness and life satisfaction as dependent variables and quality of life as an independent variable. The results showed that the psychological and physical domains of quality of life were significant predictors of happiness and satisfaction of life, where the psychological domain proved significant in predicting all four-time points: happiness today $(\beta=0.039 ; p<0.05)$, happiness throughout life $(\beta=0.043 ; p<0.05)$, current life satisfaction $(\beta=0.034 ; p<0.05)$ and life satisfaction five years from now $(\beta=0.017 ; p<0.05)$. Physical domain was similar to psychological except for current life satisfaction $(\beta=0.029$; $0.023 ; 0.014 ; \mathrm{p}<0.05)$. The environmental domain had been shown to predict happiness throughout life significantly $(\beta=0.019 ; \mathrm{p}<0.05)$ and life satisfaction five years from now $(\beta=-0.015 ; p<0.05)$. The social domain was not found to be a significant predictor. It can be concluded that improving the psychological and physical function of Indonesian people and their environmental conditions will lead them to a happier and more satisfying life.
\end{abstract}

Keywords: happiness; Indonesia; life satisfaction; quality of life

Happiness and life satisfaction are two concepts that are often used interchangeably. Happiness is defined as the degree a person assesses the quality of his or her whole life as good. It can also be defined as how much someone likes the life they lead (Veenhoven, 2012a). In the evaluation process, individuals tend to use two or more sources of information: (i) affective (i.e., how well people feel most of their life); (ii) cognitive (i.e., how much a person achieves what he or she wants in life)(Veenhoven, 2009). This research

Address for correspondence:

fredrick.purba@unpad.ac.id separated the use of happiness and life satisfaction as terms: the term 'happiness' is further associated with the dominance of the affective/emotional component. The term 'life satisfaction' involves the cognitive component more.

On a personal level, everyone wants to be happy (Diener \& Oishi, 2000; Howell et al., 2016; Seligman, 2012). Those who are happy are healthier, relatively free of various diseases (Cohen, Doyle, Turner, Alper, \& Skoner, 2003; Davidson, Mostofsky, \& Whang, 2010; Zautra, Johnson, \& Davis, 2005). Additionally, they also have a longer life expectancy 
(Steptoe \& Wardle, 2011; Xu \& Roberts, 2010). Life satisfaction is found to be related to flexibility/resilience (Beutel, Glaesmer, Decker, Fischbeck, \& Brähler, 2009), healthy behavior, physical and mental health, and self-worth (Grant, Wardle, \& Steptoe, 2009).

Experts have widely studied various factors that affect happiness and life satisfaction. Some sociodemographic factors such as age, gender, education level, employment status, marital status, and perceived health status are associated with happiness and life satisfaction (Argyle, 2013; Purba \& Fitriana, 2019; Rahayu, 2016). Aside from sociodemographic factors, the following factors also determine happiness and life satisfaction: stages of development, personality, religiosity, and social capital (Purba \& Fitriana, 2019; Rahayu, 2016; Veenhoven, 2012b).

This research focused on one aspect that is also influenced by various sociodemographic, namely quality of life (Lubetkin, Jia, Franks, \& Gold, 2005; Purba et al., 2018a; Purba et al., 2018b). Quality of life itself is defined by the World Health Organization (WHO) as an individual's perception of his/her position in life, in the cultural context and value system in which he/she lives and about his/her goals and expectations standards, and interests. WHO divides quality of life into four domains, namely physical health, psychological, social, and environmental relations (Skevington, Lotfy, \& O'Connell, 2004; The WHOQOL Group, 1998).

The results of literature exploration on Google Scholar with the keywords 'quality of life' are primarily consisted of studies in patients and marginal groups, including patients with type 2 diabetes mellitus (Arifin et al., 2019), cervical cancer patients (Endarti et al., 2015 ), residents of the Ciliwung riverbank (Purba et al., 2018b), women with breast cancer symptoms (Setyowibowo et al., 2018). While the keywords 'happiness' and 'life satisfaction' are more commonly found in studies in the general population, such as World Values Survey participants (Ball \& Chernova, 2008), general public (Baptista et al., 2016), women in Germany (Beutel et al., 2009). A study linking quality of life and satisfaction with life in the United States population found that health-related quality of life and health-related risk behaviors varied in various levels of life satisfaction among participants (Strine, Chapman, Balluz, Moriarty, \& Mokdad, 2008). No similar studies have been found in Indonesia. Therefore, this study aimed to find a relationship between quality of life with happiness and life satisfaction in Indonesian society.

\section{Method}

This research was part of a collaborative study on Bandung people's perceptions of marriage (Novianti, Purba, Noer, \& Kendhawati, 2018). This study was approved by the Health Ethics Committee, Faculty of Medicine, Padjadjaran University, Indonesia. The Ethical Approval of this study was numbered 854 / UN6.C.10 / PN / 2017.

\section{Participant and data collection}

Participants were residents of the city of Bandung and its surroundings, including late adolescence and early adulthood, aged 17-30 years old. The sampling technique used was non-probability sampling, specifically purposive sampling. Characteristics of the sample were as follows: married individuals, marriage age was under five years old, residing in Bandung, and willing to participate in research as 
evidenced by signing an informed consent form.

Data collection was carried out by five students of the Faculty of Psychology at Padjadjaran University through face-toface interviews and questionnaires. All of them have passed the 'Observation and Interview' course as requirements to become interviewers in this study. Various strategies were used to recruit participants, including personal contacts, recruitment in public locations such as mosques, schools (high schools in Bandung), and youth clubs. The interviewers also asked participants to introduce other potential participants. Signed consents for participation (informed consent) were obtained from all participants.

\section{Instrument}

Sociodemographic data were collected using a questionnaire that explored information participants' age, gender, and education level.

Quality of life was measured using the WHOQOL-BREF questionnaire published by WHO in 1998 (Skevington et al., 2004; The WHOQOL Group, 1998). WHOQOL Group developed WHOQOL-BREF as a shortened version of WHOQOL-100. This questionnaire has 26 questions, two of which measure the overall quality of life of participants and general health according to their assessment and 24 other questions are divided into four domains: physical health (e.g., "Do you have enough energy for daily activities?"), psychological ( for example "How much do you enjoy your life?"), social relations (e.g., "How satisfied are you with your personal/social relationships?"), and the environment (e.g., "How satisfied are you with the conditions where you live now?"). Each item is scored on a scale from 1 to 5 . The score was changed to a scale between 0 and 100 for this study, with 0 being the most unfavorable quality of life and 100 being the most favorable (5). Previous studies in Indonesia obtained internal consistency values ranging from 0.57 to 0.78 (Setyowibowo et al., 2018) and the testretest reliability coefficient (Intraclass correlation coefficient) between 0.70 to 0.79 (Purba et al., 2018a). For this study sample, the internal consistency of WHOQOLBREF ranged from 0.42 to 0.70 .

Happiness was measured using the Happiness thermometer questionnaire. This instrument is an 11-point scale for happiness assessment at two-time points: today and overall lifetime. There are 11 face images (smileys) presented horizontally, starting from 0 , represented by 'sad face,' up to 5, represented by 'neutral face,' up to 10 , represented by 'smiling face.' Previous studies had shown that the Happiness Thermometer has an excellent test-retest reliability, a significant convergent validity coefficient, and can find small differences in happiness (Baptista et al., 2016; Fordyce, 1977; Fordyce, 1988). Previous studies in Indonesia had an internal consistency value of 0.78 (Purba et al., 2018a). For this study sample, the internal consistency of the happiness thermometer scale was 0.63.

Self-Anchoring Cantril Striving Scale was used to measure life satisfaction (Cantril, 1966). This measuring instrument is presented in the form of a vertical ladder drawing with 11 steps. The lowest rung is marked with a value of 0 (worst), and the top rung is marked with a value of 10 (best). Participants were asked to rate how satisfied they were with their lives at twotime points: now and in five years. This measuring instrument is widely used in international surveys such as the Gallup World Poll (Bjørnskov, 2010). Previous studies in Indonesia found an internal 
consistency value of 0.74 (Purba et al., 2018a). For this study sample, the internal consistency of the life satisfaction scale was 0.47 .

\section{Statistical analysis}

Sociodemographic data on participants' gender and education level were analyzed by percentage, meanwhile age were analyzed by descriptive statistics, namely the average and standard deviations. Mean and standard deviations were also calculated for the domains of quality of life, and the time points of happiness and life satisfaction. Pearson correlation test was conducted to examine the relationship between quality of life, happiness, and life satisfaction. Bonferroni correction was carried out because the test was carried out several times. To interpret the correlation test results, the criteria of Cohen were used: 0.2 to 0.5 are small, 0.5 to 0.8 are moderate, and more significant than 0.8 is considered substantial (Cohen, 1988). Multiple regression test was done by placing each time point of happiness (i.e., today and overall life) and life satisfaction (i.e., current and in five years) as the dependent variable. The four domains of quality of life (physical health, psychological, relationships, social, and environmental) act as independent variables. P-values below 0.05 were considered significant. All statistical analyzes were performed with the Stata software 13.0 edition.

\section{Results}

This study involved 370 participants who filled out the measuring instrument completely. The average age of participants was 20.7 years old, the majority were men $(55.7 \%)$ and had secondary education (junior-high school; 57.0\%). The details of the participant characteristics are listed in Table 1.

Table 2 shows a description of quality of life, happiness, and life satisfaction of the participants. Physical domain of quality of life was the highest (average; $S D$ $=67.90 ; 10.73$ ) and social domain was the lowest $(62.93 ;$ 13.42). Happiness data showed that the two time points did not differ greatly, 6.53 for today and 6.96 for the lifetime. As for the current life satisfaction, the average score was 6.39 and 9.02 for the next five years.

Table 1.

Participants' Sociodemographic Characteristics $(\mathrm{N}=370)$

\begin{tabular}{lcc}
\hline Characteristics & Mean & Standard Deviation \\
\hline Age & 20.7 & 3.5 \\
\cline { 2 - 3 } & & N \\
\cline { 2 - 3 } Sex & 206 & 55.7 \\
$\quad$ Male & 164 & 44.3 \\
Female & & \\
& & \\
Education & & \\
$\quad$ Secondary & 211 & 57.0 \\
$\quad$ Higher & 159 & 43.0 \\
\hline
\end{tabular}

a Secondary: Junior High School and High

School; Higher: Diploma and Bachelor

Table 2.

Quality of Life, Happiness, and Life Satisfaction Scores

\begin{tabular}{lrr}
\hline \multicolumn{1}{c}{ Variable } & Mean & $\begin{array}{c}\text { Standard } \\
\text { Deviation }\end{array}$ \\
\hline Quality of life & 67.90 & 10.73 \\
$\quad$ Physical & 65.53 & 11.87 \\
Psychological & 62.93 & 13.42 \\
Social & 63.80 & 11.45 \\
Environmental & & \\
Happiness & 6.53 & 1.96 \\
$\quad$ Today & 6.96 & 1.74 \\
$\quad$ Lifetime & & \\
Life satisfaction & 6.39 & 1.58 \\
$\quad$ Current & 9.02 & 1.19 \\
$\quad$ In five years & & \\
\hline
\end{tabular}


Table 3 presents the correlations between the four domains of quality of life with happiness and life satisfaction. It can be seen that all four domains were significantly related to lifetime happiness and current life satisfaction. For today's happiness, only the physical and psychological domains were significantly related, while the life satisfaction for the next five years was related to the physical domain, psychological, and social quality of life. Although significant, the resulting correlation was relatively small (correlation coefficient between 0.078 and 0.349 .

The results of multiple linear regression tests showed some interesting results (see Table 4). The psychological domain of quality of life was found to be a significant predictor of today and lifetime happiness and also current life satisfaction and life satisfaction in five years (P-value $<0.05)$. The physical domain also showed similar results except for current life satisfaction, where it was not found to be significant $(P$-value $=0.204)$. The environmental domain became a significant predictor of lifetime happiness and life satisfaction in five years. The social domain was found to be insignificant as a predictor for happiness and life satisfaction.

\section{Discussion}

This research explored the relationship between quality of life with happiness and life satisfaction according to the perspective of individuals aged 17-30 years old in the city of Bandung. The results showed that the psychological and physical domains of quality of life were significant predictors of happiness and life satisfaction. The psychological domain proved to be significant in predicting the

Table 3.

Correlations between Quality of Life, Happiness, and Life Satisfaction Scores

\begin{tabular}{lcccc}
\hline \multicolumn{1}{c}{ Domain } & $\begin{array}{c}\text { Today's } \\
\text { happiness }\end{array}$ & $\begin{array}{c}\text { Lifetime } \\
\text { happiness }\end{array}$ & $\begin{array}{c}\text { Current life } \\
\text { satisfaction }\end{array}$ & $\begin{array}{c}\text { Life satisfaction } \\
\text { in 5 years }\end{array}$ \\
\hline Physical & $0.259^{*}$ & $0.324^{*}$ & $0.223^{*}$ & $0.204^{*}$ \\
Psychological & $0.290^{*}$ & $0.408^{*}$ & $0.306^{*}$ & $0.213^{*}$ \\
Social & 0.121 & $0.184^{*}$ & $0.170^{*}$ & $0.180^{*}$ \\
Environmental & 0.145 & $0.309^{*}$ & $0.171^{*}$ & 0.042 \\
\hline
\end{tabular}

* P-value $<0.05$

Table 4.

Multiple Linear Regression Results between Happiness, Life Satisfaction, and Quality of Life

\begin{tabular}{|c|c|c|c|c|c|c|c|c|c|c|c|c|}
\hline \multirow{2}{*}{$\begin{array}{l}\text { Quality } \\
\text { of life }\end{array}$} & \multicolumn{3}{|c|}{ Today's happiness } & \multicolumn{3}{|c|}{ Lifetime happiness } & \multicolumn{3}{|c|}{ Current life satisfaction } & \multicolumn{3}{|c|}{$\begin{array}{c}\text { Life satisfaction in } 5 \\
\text { years }\end{array}$} \\
\hline & $\begin{array}{l}\text { Coeffi- } \\
\text { cient }\end{array}$ & $\mathrm{SE}^{\mathrm{a}}$ & P-value & $\begin{array}{l}\text { Coeffi- } \\
\text { cient }\end{array}$ & SE & P-value & $\begin{array}{l}\text { Coeffi- } \\
\text { cient }\end{array}$ & SE & P-value & $\begin{array}{c}\text { Coeffi- } \\
\text { cient }\end{array}$ & SE & P-value \\
\hline Fisik & 0.029 & 0.011 & 0.009 & 0.023 & 0.009 & 0.014 & 0.011 & 0.009 & 0.204 & 0.014 & 0.007 & 0.043 \\
\hline Psikologis & 0.039 & 0.011 & $<0.001$ & 0.043 & 0.009 & $<0.001$ & 0.034 & 0.009 & $<0.001$ & 0.017 & 0.007 & 0.009 \\
\hline Sosial & -0.005 & 0.009 & 0.520 & -0.007 & 0.007 & 0.311 & 0.003 & 0.007 & 0.645 & 0.010 & 0.005 & 0.053 \\
\hline Lingkungan & -0.004 & 0.010 & 0.672 & 0.019 & 0.009 & 0.033 & -0.001 & 0.008 & 0.939 & -0.015 & 0.006 & 0.017 \\
\hline
\end{tabular}


four-time points: today and lifetime happiness and current life satisfaction and the next five years, while the physical domain was similar to the psychological domain, except for current life satisfaction. Another result was that the environmental domain had been shown to predict lifetime happiness and life satisfaction in five years significantly.

The physical domain of quality of life, including daily activities, the ability to walk/move, pain and discomfort, rest, and the ability to work were found to be significant predictors of happiness, both today and lifetime. The statement "those who are healthier tend to be happier" was also in line with studies in Indonesia (Rahayu, 2016) and rural Chinese communities (Knight, Lina, \& Gunatilaka, 2009). The psychological domain, which includes feelings, self-confidence, spirituality/religion/personal belief, learning, memory, and concentration, was also a significant predictor of happiness. Something similar was found in a study in Yogyakarta that stress has significant negative relation to student happiness (Evanjeli, 2012).

The physical and psychological domains of quality of life were related to life satisfaction in this study. This finding is also in line with previous studies in the general population of the United States (Strine et al., 2008). The findings showed that people with low life satisfaction are four times more likely to experience physical stress, 17 times more likely to experience mental stress, and 41.4 times more likely to exhibit depressive symptoms over the past 14 days compared to people with high life satisfaction. This result stands even after controlling for the sociodemographic characteristics of the participants. Other studies involving the general population in China also found that mental health problems significantly reduced life satisfaction (Graham, Zhou, \& Zhang, 2017)

The environmental domain of quality of life, consisting of the safety and perceived physical security, home environment, opportunities for recreation, physical environment, and transportation used, showed contradictory results. The finding suggested that although those variables are positive predictors for lifetime happiness, they are negatively correlated with life satisfaction in five years. For happiness, this can be understood, but harmful to life satisfaction seemed contradictory. This could happen because there were concerns about environmental conditions in the future, which affected how participants assessed satisfaction with their lives (Ojala, 2005). Similar contradictory results were shown by previous studies on the banks of the Ciliwung river: those who live on the banks of the river are less happy but are more satisfied with their lives than those who do not live on the banks of the river (Purba et al., 2018b).

The social domain of quality of life was insignificant as a predictor of happiness and life satisfaction in this study. This finding is different from previous studies in Australia and the United States (Dunkley, Zuroff, \& Blankstein, 2003; Gallagher \& VellaBrodrick, 2008). One alternative explanation that can be delivered is that the participant's possible response to the satisfaction items of sexual relations distracted domain scores because sexual relations were quite difficult for participants to respond, especially those who were not married. After further analysis with social domain scores that did not include sexual relationship points, it was found that the social domain of 
quality of life was a significant predictor of life satisfaction in five years. Interestingly, greater satisfaction with personal relationships and social support from friends increases how people anticipate their lives in the future.

One exciting result was that participants in this study could be said to be optimistic. Life satisfaction in five years was projected to be higher than current life satisfaction $(t=-25.58 ; P$-value $<0.001)$. This optimism for the future was also found by research on 3565 Indonesian youth participants. Participants had a great desire for future work-related (ie, wanting to work as a professional), high education, and a long career (Nilan, Parker, Bennett, \& Robinson, 2011).

Some limitations of this study need to be noted. First, the study's location is limited to one city, namely Bandung, and the non-probability sample determination method caused the need for caution to generalize the results to other populations. Second, cross-sectional research methods limited the interpretation of results as relationships or predictions, not causation. Although it is found that three of the four domains of quality of life can predict happiness and life satisfaction, it can also be the opposite: happiness and life satisfaction predict the quality of life, as found in several previous studies (see for example: (Pettit, Kline, Gencoz, Gencoz, \& Joiner, 2001)).

\section{Conclusion}

This research found that an individual's quality of life, specifically the physical, psychological, and environmental domain, can predict happiness and life satisfaction, while the social domain does not. In the Indonesian context, optimal physical and psychological functions are vital requirements for society, both in undergoing education, working, establishing personal relationships, and others. When someone experiences problems in physical function, such as chronic illness or disability, economic burdens (e.g., unable to work), emotional (e.g., stress, anxiety, depression), and social (e.g., being a burden to others), the burden becomes more prominent for the individual. This situation could result in causing a low level of happiness and life satisfaction. At the same time, the quality of relationships with others, or the support of people around does not necessarily guarantee happiness and overall life satisfaction.

It was also found that Indonesians, especially in Bandung city, were optimistic for their future. Although the personal and socioeconomic situations may be perceived as hard by the people of Indonesia, religious beliefs and the value of gratitude that run thick in Indonesian society may be the foundation of optimism for the future.

\section{Suggestion}

Further research is advised to use a longitudinal design. For example, each year within the five years, researchers could investigate the causal effect of quality of life on happiness and life satisfaction. Additionally, they could also examine whether the predicted life satisfaction of the respondents in the next five years is accurate. Similar studies can also be carried out on groups of patients with chronic illnesses and groups of people with psychiatric problems considering the importance of physical and psychological functions.

On a practical level, these results support the importance of formal and informal efforts that can be carried out by governments, related institutions, and 
individuals to stimulate the physical and psychological aspects of Indonesian people to be able to increase their happiness and life satisfaction and later become a more productive and prosperous generation. Also, efforts should be made to provide psychological services by mental health practitioners (e.g., psychologists) to be included in health services covered by social security programs in the field of health (BPJS Kesehatan) so that everyone can access them.

\section{Funding}

This research was awarded a Fundamental Research Grant from Universitas Padjadjaran (RFU) in 2017. Contract Number: 872/UN6.3.1/LT/2017.

\section{Authors' contribution}

Langgersari Elsari Novianti made conceptualizations, fund acquisitions, methodology, research administration, resources, initial writing, reviewing, and editing. Fredrick Dermawan Purba made conceptualizations, methodology, formal analysis, writing - initial script, writing reviewing, and editing. Esti Wungu worked on research administration, resources, reviewing and editing.

\section{Conflict of interest}

There is no conflict of interests in regards to this research.

\section{Orcid id}

Fredrick Dermawan Purba

https://orcid.org/0000-0002-7336-3043

\section{References}

Argyle, M. (2013). The psychology of happiness. London: Tylor \& Francis Group.

Arifin, B., Idrus, L. R., van Asselt, A. D. I., Purba, F. D., Perwitasari, D. A.,
Thobari, J. A., Postma, M. J. (2019). Health-related quality of life in Indonesian type 2 diabetes mellitus outpatients measured with the Bahasa version of EQ-5D. Quality of Life Research. doi:10.1007/s11136-019$\underline{02105-\mathrm{Z}}$

Ball, R., \& Chernova, K. (2008). Absolute income, relative income, and happiness. Social Indicators Research, 88(3), 497-529. doi:10.1007/s11205$\underline{007-9217-0}$

Baptista, A., Camilo, C., Santos, I., de Almeida Brites, J., Rosa, J. B., \& Fernandez-Abascal, E. G. (2016). What are people saying when they report they are happy or life satisfied. Anales de Psicologia, 32(3), 803-809.

doi: $\underline{10.6018 / \text { analesps.32.3.229121 }}$

Beutel, M. E., Glaesmer, H., Decker, O., Fischbeck, S., \& Brähler, E. (2009). Life satisfaction, distress, and resiliency across the life span of women. Menopause, 16(6), 1132-1138. doi: 10.1097/gme.0b013e3181a857f8

Bjørnskov, C. (2010). How comparable are the gallup world poll life satisfaction data? Journal of Happiness Studies, 11(1), 41-60. doi: 10.1007/s10902-0089121-6

Cantril, H. (1966). The pattern of human concerns. New Brunswick, N.J.: Rutgers University Press.

Cohen, J. (1988). Statistical power analysis for the behavioral sciences 2nd ed. New York: Erlbaum Associates, Hillsdale.

Cohen, S., Doyle, W. J., Turner, R. B., Alper, C. M., \& Skoner, D. P. (2003). Emotional style and susceptibility to the common cold. Psychosomatic Medicine, 65(4), 652-657.

Davidson, K. W., Mostofsky, E., \& Whang, W. (2010). Don't worry, be happy: positive affect and reduced 10-year incident coronary heart disease: the 
Canadian Nova Scotia Health Survey. European Heart Journal, 31(9), 1065-1070. doi: 10.1093/eurheartj/ehp603

Diener, E., \& Oishi, S. (2000). Money and happiness: Income and subjective wellbeing across nations Culture and subjective well-being. Cambridge, MA: The MIT Press.

Dunkley, D. M., Zuroff, D. C., \& Blankstein, K. R. (2003). Self-critical perfectionism and daily affect: Dispositional and situational influences on stress and coping. Journal of Personality and Social Psychology, 84(1), 234.

Endarti, D., Riewpaiboon, A., Thavorncharoensap, M., Praditsitthikorn, N., Hutubessy, R., \& Kristina, S. A. (2015). Evaluation of health-related quality of life among patients with cervical cancer in Indonesia. Asian Pacific Journal of Cancer Prevention, 16(8), 3345-3350.

Evanjeli, L. A. (2012). Hubungan antara stres, somatisasi, dan kebahagiaan. (Unpublished master thesis). Faculty of Psychology Universitas Gadjah Mada, Yogyakarta.

Fordyce, M. W. (1977). Development of a program to increase personal happiness. Journal of Counseling Psychology, 24(6), 511-521. doi: 10.1037/0022-0167.24.6.511

Fordyce, M. W. (1988). A Review of research on the happiness measures: A sixty second index of happiness and mental health. Social Indicators Research, 20(4), 355-381.

Gallagher, E. N., \& Vella-Brodrick, D. A. (2008). Social support and emotional intelligence as predictors of subjective well-being. Personality and Individual Differences, 44(7), 15511561.
Graham, C., Zhou, S., \& Zhang, J. (2017). Happiness and health in China: The paradox of progress. World Development, 96, 231-244. doi: 10.1016/j.worlddev.2017.03.009

Grant, N., Wardle, J., \& Steptoe, A. (2009). The relationship between life satisfaction and health behavior: A cross-cultural analysis of young adults. International Journal of Behavioral Medicine, 16(3), 259-268. doi: 10.1007/s12529-009-9032-x

Howell, K. H., Coffey, J. K., Fosco, G. M., Kracke, K., Nelson, S. K., Rothman, E. F., \& Grych, J. H. (2016). Seven reasons to invest in well-being. Psychology of Violence, 6(1), 8.

Knight, J., Lina, S., \& Gunatilaka, R. (2009). Subjective well-being and its determinants in rural China. China Economic Review, 20(4), 635-649.

Lubetkin, E. I., Jia, H., Franks, P., \& Gold, M. R. (2005). Relationship among sociodemographic factors, clinical conditions, and health-related quality of life: examining the EQ-5D in the U.S. general population. Quality of Life Research, 14(10), 21872196. doi: $10.1007 / \mathrm{s} 11136-005-8028-5$

Nilan, P., Parker, L., Bennett, L., \& Robinson, K. (2011). Indonesian youth looking towards the future. Journal of Youth Studies, 14(6), 709728.

doi:

$\underline{10.1080 / 13676261.2011 .580523}$

Novianti, L. E., Purba, F. D., Noer, A. H., \& Kendhawati, L. (2018). Pernikahan dalam perspektif masyarakat Bandung. Jurnal Psikogenesis, 6(1), 7990.

Ojala, M. (2005). Adolescents' worries about environmental risks: Subjective well-being, values, and existential dimensions. Journal of Youth Studies, 8(3), 331-347. 
Pettit, J. W., Kline, J. P., Gencoz, T., Gencoz, F., \& Joiner, T. E. (2001). Are happy people healthier? The specific role of positive affect in predicting self-reported health symptoms. Journal of Research in Personality, 35(4), 521-536. doi: 10.1006/jrpe.2001.2327

Purba, F. D., \& Fitriana, T. S. (2019). Sociodemographic determinants of reporting mental health problems in Indonesian urban population. Psychological Research on Urban Society, 2(1), 59-64.

Purba, F. D., Hunfeld, J. A., Iskandarsyah, A., Fitriana, T. S., Sadarjoen, S. S., Passchier, J., \& Busschbach, J. J. (2018a). Quality of life of the Indonesian general population: Testretest reliability and population norms of the EQ-5D-5L and WHOQOL-BREF. PloS One, 13(5), e0197098.

Purba, F. D., Hunfeld, J. A. M., Fitriana, T. S., Iskandarsyah, A., Sadarjoen, S. S., Busschbach, J. J. V., \& Passchier, J. (2018b). Living in uncertainty due to floods and pollution: the health status and quality of life of people living on an unhealthy riverbank. BMC Public Health, 18(1), 782. doi: 10.1186/s12889-018-5706-0

Rahayu, T. P. (2016). Determinan kebahagiaan di Indonesia. Jurnal Ekonomi dan Bisnis, 19(1), 149-170.

Seligman, M. E. (2012). Flourish: A visionary new understanding of happiness and well-being. New York: Simon and Schuster.

Setyowibowo, H., Purba, F. D., Hunfeld, J. A. M., Iskandarsyah, A., Sadarjoen, S. S., Passchier, J., \& Sijbrandij, M. (2018). Quality of life and health status of Indonesian women with breast cancer symptoms before the definitive diagnosis: A comparison with Indonesian women in general. PloS One, 13(7), e0200966. doi: 10.1371/journal.pone.0200966

Skevington, S. M., Lotfy, M., \& O'Connell, K. A. (2004). The World Health Organization's WHOQOL-BREF quality of life assessment: psychometric properties and results of the international field trial. A report from the WHOQOL group. Quality of Life Research, 13(2), 299-310.

Steptoe, A., \& Wardle, J. (2011). Positive affect measured using ecological momentary assessment and survival in older men and women. Proceedings of the National Academy of Sciences, 108(45), 18244. doi:10.1073/pnas.1110892108

Strine, T. W., Chapman, D. P., Balluz, L. S., Moriarty, D. G., \& Mokdad, A. H. (2008). The associations between life satisfaction and health-related quality of life, chronic illness, and health behaviors among U.S. community-dwelling adults. Journal of Community Health, 33(1), 40-50. doi: $10.1007 / \mathrm{s} 10900-007-9066-4$

The WHOQOL Group. (1996). WHOQOLBREF: Introduction, administration, scoring and generic version of the assessment. Retrieved from https://www.who.int/mental health/ media/en/76.pdf

The WHOQOL Group. (1998). Development of the World Health Organization WHOQOL-BREF quality of life assessment. Psychological Medicine, 28(3), 551-558.

Veenhoven, R. (2009). How do we assess how happy we are? Tenets, implications and tenability of three theories. Happiness, Economics and Politics, 45-69.

Veenhoven, R. (2012a). Happiness: Also known as "Life Satisfaction" and "Subjective Well-Being". In K. C. 


\section{QUALITY OF LIFE, HAPPINESS AND LIFE SATISFACTION}

Land, A. C. Michalos, \& M. J. Sirgy (Eds.), Handbook of social indicators and quality of life research (pp. 63-77). Dordrecht: Springer Netherlands.

Veenhoven, R. (2012b). Measures of happiness: World database of happiness. Rotterdam: Erasmus University Rotterdam, The Netherlands.

Xu, J., \& Roberts, R. E. (2010). The power of positive emotions: It's a matter of life or death-Subjective well-being and longevity over 28 years in a general population. Health Psychology, 29(1), 9-19. doi: $\underline{10.1037 / \mathrm{a} 0016767}$

Zautra, A. J., Johnson, L. M., \& Davis, M. C. (2005). Positive affect as a source of resilience for women in chronic pain. Journal of Consulting and Clinical Psychology, 73(2), 212-220. doi: 10.1037/0022-006X.73.2.212 